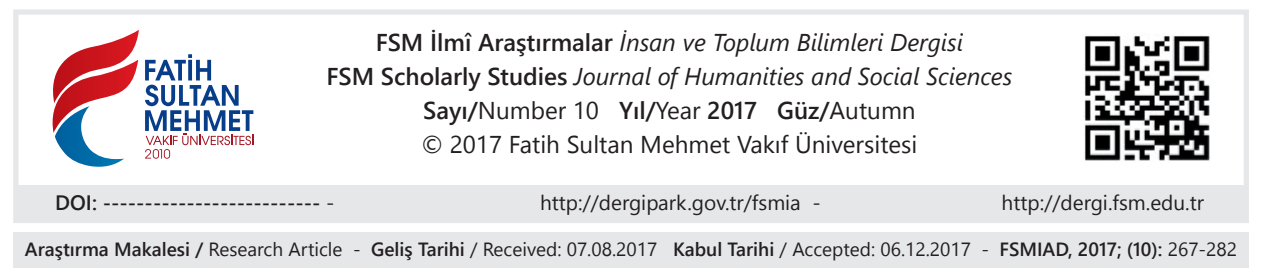

\title{
Yeniden-Yazım Örneği Olarak Mahmut ile Meryem Romanı
}

Hanife Özer*

\section{Öz}

Bu çalışmada çağdaş Azerbaycan edebiyatının önemli isimlerinden biri olan Elçin Efendiyev'in Mahmut ile Meryem romanı yeniden-yazma yöntemine göre incelenecektir. 1984 yılında kitap halinde yayımlanan Mahmut ile Meryem romanında yazar, Asl ve Kerem hikâyesini alt metin olarak almış ve yeniden-yazma yöntemiyle modern bir metin üretmiştir. Efendiyev, eserini yeniden yazarken hikâyenin olay örgüsüne bağlı kalmış; ancak mesaj, olay, kişi, zaman, mekân, tür vb. unsurlara önemli ölçüde müdahalede bulunmuştur. Aslı ve Kerem hikâyesi karşısında romanına bireysel ve toplumsal olmak üzere başka temalar yerleştirmiştir. Kişi kadrosunun genişletildiği gözlenen romanda, hikâyedeki yalın kat kişilere karşı psikolojik boyutları olan kişiler yerleştirmiştir. En önemli değişiklik ise romanın temel iletisinde sezilir. Aslı ve Kerem hikâyesi aşk iletisi üzerine kurulmuşken romanın iletisi insan sevgisidir.

Anahtar Kelimeler: Azerbaycan, Elçin Efendiyev, Mahmut ile Meryem, Asll ve Kerem, yeniden-yazma, hikâye, roman.

\section{The Novel Mahmut and Meryem: Instance of Re-Writting}

\section{Abstract}

This study will examine the novel called Mahmut with Meryem by Elcin Efendiyev, one of the most important names in contemporary Azerbaijani literature, according to the "re-writing" method. In Mahmut with Meryem, which was published in 1984 as a novel, the author took the story of Asll and Kerem as a sub-text and produced a modern text by using the re-writing method. Although whilst re-writing her book Efendiyev remained close to the plot; she interfered significantly with the elements such as message, event, people, time, place, genre, etc.. Some individual and social themes have been added on top of the story of Asll and Kerem. As well as expanding the cadre people with psychological depth have been placed instead of certain the plain characters in the novel. The most significant change is felt in the basic delivery of the novel. While the story of Asl and Kerem is based on romantic love, the message of the novel is human love.

Keywords: Azerbaijan, Elçin Efendiyev, Mahmut with Meryem, Asll and Kerem, re-writing, story, novel.

* Yrd. Doç. Dr., Abant İzzet Baysal Üniversitesi, Fen Edebiyat Fakültesi Türk Dili ve Edebiyatı Bölümü, Bolu/Türkiye, hanifeoz@gmail.com, orcid.org/0000-0002-7547-3174 


\section{Giriş}

Çağdaş Azerbaycan edebiyatında Elçin Efendiyev tarafından kaleme alınan ve 1982 y1lında tefrika, 1984 yılında ise kitap olarak yayımlanan Mahmut ile Meryem romanı, edebiyatta yeniden-yazma yönteminin özelliklerini taşıyan, başka bir ifadeyle geleneğin içinden Aslı ve Kerem anlatısına bağlı olarak yeniden yazılan bir eserdir. Efendiyev, yer yer fantastik özellikler taşıyan romanında olay örgüsü, kişiler, zaman, mekân, yazım biçimi vb. unsurlar bakımından alt (asıl, temel, ana, model, ilk) metne büyük ölçüde bağl1 kalmakla birlikte yeniden-yazma yöntemiyle alt metni çağının edebiyat imkânları ve çağdaş bir romancının bakış açısıyla yeniden kurgulamıştır. Yazar, eserini kaleme alırken modern romanın hemen bütün tekniklerini kullanmış, böylece alt metni değiştirmiş, dönüştürmüş, yeni bir edebî üretim olarak yeni ve farklı bir okur kitlesine hitap eder duruma getirmiştir. Bizim çalışmamızda da Mahmut ile Meryem romanı yeniden yazılırken yazarın alt metne bağlı kaldığı hususlar ile ikincil metin bünyesindeki tasarrufları tespit edilerek iki metin arasındaki ilişkiler, karşılaştırma yöntemiyle irdelenecektir.

Edebiyatta "metinlerarası ilişkiler" bağlamında ele alınan "yeniden-yazma," daha önce ortaya konmuş bir metnin/metinlerin ya da o metne/metinlere ait kesitin/kesitlerin çeşitli amaçlar doğrultusunda değiştirilerek, dönüştürülerek yeniden üretilmesi yöntemidir. Kubilay Aktulum “yeniden-yazma” olgusunu genel olarak, hangi türden olursa olsun önceki bir metnin onu taklit eden, dönüştüren, açık ya da kapalı bir biçimde ona gönderen bir başka metinde yinelenmesi olarak tanımlanır. Ayrışık unsurları, başka metinlere ait parçaları tutarlı bir bütün içerisinde bir araya getirmek, onları düzenleyerek aralarında uyum sağlamak, böylelikle yeni bir metin ortaya çıkarmak, böylece yeni anlam alanları aramak ve yaratmak bu yöntemin temelinde yatan sebepler olarak sıralanır. ${ }^{1}$

Yeniden-yazma bir yazarın anonim yahut başka yazarlara ait metinleri değiştirip dönüştürmesi yoluyla olabileceği gibi, bir yazarın daha önce yazdığ 1 kendi metnini/metinlerini daraltmak, genişletmek, derinleştirmek, düzeltmek vb. amaçlar doğrultusunda da gerçekleştirilebilir. Bu bakımdan da söz konusu yöntemi daha geniş bir yelpazede düşünmek gerekir. Nitekim tercüme, aktarma, uyarlama, özetleme, çoğaltma vb. yazma faaliyetlerinin de yeniden-yazma kapsamında değerlendirilmesi söz konusudur. Bununla birlikte yeniden-yazma daha çok tarihsel süreç içinde tanınıp bilinen, geniş kitleler tarafından rağbet edilen eserlerin yeniden üretilmesi yönünde gelişir. Örneğin İlyada ve Odise anlatılar1 Batı edebiyatında pek çok esere ilham veya model olmuş, pek çok eser için kaynak metin işlevi görmüştür. Yine Oedip, Don Juan söylenleri; Médée" ya da

1 Kubilay Aktulum, Metinlerarası İlişkiler, Öteki Yayınları, Akara 2000, s. 236. 
Cassandre dramlarının yüzlerce versiyonu vardır. ${ }^{2}$ Türk edebiyatında ise özellikle klasik dönemde Kur'an'daki, Tevrat'taki bazı hikâyeler (Yusuf ile Züleyha) ile Doğu edebiyatının temel metinlerinden olan Leyla ile Mecnun, Vâmık ile Azra, Hüsrev ile Şirin hikâyeleri birçok şair tarafından tekrar yazılmıştır. Yine halk edebiyatı içinde Kerem ile Aslı, Ferhat ile Şirin, Köroğlu vb. anlatılar farklı sanatkârlar tarafından yeniden-yazım yöntemiyle farklı okur kitleleri için yeniden üretilmiştir. Yeniden-yazma, modern dönem Türk edebiyatında da sanatçılar tarafından başvurulan bir yöntem olmuştur. Ömer Seyfettin'in “Başını Vermeyen Şehit" hikâyesi Peçevî Tarihi'nden alınarak yeniden kurgulanmıştır. Adalet Ağaoğlu, Halide Edip Adıvar'ın Sinekli Bakkal romanındaki başkişi Rabia'ya atıfla "Rabia'nın Dönüşü” öyküsünü yeniden yorumlamıştır. Nazan Bekiroğlu Yusuf ile Züleyha anlatısını postmodern ögelerle yeniden kaleme almıştır. Murathan Mungan da "Dumrul ile Azrail" başlıklı hikâyesini Dede Korkut hikâyelerinden olan "Duha Koca Oğlu Deli Dumrul”dan yola çıkarak yeniden yazmıştır. Halit Ziya Uşaklıgil, Mai ve Siyah, Aşk-ı Memnu; Ayfer Tunç, Evvelotel vb. metinler, bizzat yazarları tarafından tekrar kaleme alınmıştır. Yine halk hikâyelerimizden Köroğlu İlhan Berk, klasik Türk edebiyatında birçok şairin yorumladığı Leyla ile Mecnun mesnevisi ise Sezai Karakoç tarafından modern tekniklerle ve yirminci asır yazarlarının bakış açılarıyla yeniden yazılmıştır.

Türk edebiyatında yeniden yazılan eserler arasında "en şanslı" olanlardan biri de Kerem ile Aslı hikâyesidir. M. Fuat Köprülü tarafından 17. asırda teşekkül ettiği tahmin edilen ${ }^{3}$ hikâye, on dokuzuncu asırdan itibaren edebiyatımızda modern hikâye, tiyatro, opera, şiir gibi sanat ve edebiyat türlerinde farklı sanatç1lar tarafından yeniden yorumlanmaya çalışılmıştır. Diğer yandan Kerem ile Aslı hikâyesi Türk edebiyatının sadece Anadolu sahasında değil, Türk coğrafyasının diğer edebiyatlarında da yaşayan, çeşitli varyantlarına rastlanan bir anlatıdır. İnceleme konumuz olan Mahmut ile Meryem romanı da Kerem ile Aslı (Azerbaycan edebiyatında Esli ve Kerem) hikâyesinin Azerbaycan varyantına dayanmaktadır. ${ }^{4}$ Modern romanın hemen bütün teknik özelliklerini bünyesinde taşıyan Mahmut ile Meryem, her ne kadar sözlü geleneğe ait bir anlatıya bağlı olsa da, söz konusu anlatının bire bir tekrarı veya taklidi değildir. Elçin Efendiyev romanında, sanatın sahip olduğu özgürlük ve yeniden-yazmanın sağladığı imkânlar doğrultusunda

2 Kubilay Aktulum, "Yenidenyazm," Frankofoni (Ortak kitap), Ankara 2006, nr. 18, s. 159.

3 M. Fuat Köprülü, Türk Edebiyatı Ders Notları (Hz. Y.K. Taştan), Akçağ Yayınları, Ankara 2015, s. 347. Şükrü Elçin; Pertev Naili Boratav ve Sadettin Nüzhet Ergun'un da Kerem ile Aslı hikâyesinin teşekkül dönemini 17. asır olarak tahmin ettikleri bilgisini verir. Bkz. Şükrü Elçin, Kerem ile Aslı Hikâyesi, Akçă̆ Yay., Ankara, 2000, s.60.

4 Çalışmamızda Ehliman Ahundov, Memmed Hüseyn Tehmasib'in hazırladığı ve beş cilt tutarındaki Azerbaycan Destanları adlı çalışmada yer alan metin kullanılmıştır. Bkz. Tehmasib ve Ahundov, "Esli ve Kerem," Azerbaycan Dastanları, Lider Neşriyat, C., 2, Bakü, 2005. 
hem bireyi hem toplumu hem de insanlığı, bunların düştükleri çıkmazları kurguya taşıyarak çağdaş bir metin üretmiştir.

\section{Yeniden-yazım örneği olarak Mahmut ile Meryem}

Türkiye'deki ilk baskısı İldeniz Kurtulan'ın aktarımıyla 1994 yılında yayımlanan Mahmut ile Meryem, sonraki yıllarda Ali Duymaz'ın aktarımıyla yayımlanmıştır. Eserin sunuş yazısında Ali Duymaz, Azerbaycan'da yaygın olmamakla birlikte bu tür romanların "romanlaşan destan" veya "destanlaşan roman" gibi tamlamalarla ifade edildiğini kaydeder. Duymaz, yine aynı yazısında söz konusu hikâye ile roman arasındaki bazı benzerliklere ve farklılıklara da dikkat çeker. ${ }^{5}$

Yapısal yahut anlamsal olabileceği gibi, sadece yapısal veya sadece anlamsal da olabilen yeniden-yazma yönteminde hemen her zaman ikincil metinde alt metne birtakım ilavelerin yapıldığı görülür. Hatta bu ilaveler yöntem açısından zorunludur denebilir. Zira alt metni açmayan, genişletmeyen, anlamsal bakımdan yeni boyutlar kazandırmayan ikincil metin, yeni bir yaratım yahut üretim sayılmayacak, ilk metni tekrardan öteye gitmeyecektir. Efendiyev de Mahmut ile Meryem romanında yukarıda kaydettiğimiz gibi Kerem ile Aslı hikâyesine bağlı kalmakla birlikte alt metin karşısında tür, anlatıcı, tasvir, tahlil, dil; olay, kişi, zaman, mekân, ileti gibi unsurları detaylandırmış, hikâyedeki birtakım unsurlara romanında yer vermemiş, hikâyede olmayan birtakım unsurları ise romanına dâhil etmiştir. Böylece Efendiyev, ikincil metin olan romanını, alt metne karşı teknik bakımdan daha tutarlı, tematik bakımdan daha zengin, anlamsal bakımdan da daha derin kılmıştır. Nitekim iki metni karşılaştırdığımızda ilk metnin teması aşk iken ikinci metnin temasının "insanın değeri," başka bir ifadeyle insan sevgisi olduğu söylenebilir. Diğer temalara bakıldığında ise hikâyede okuduğumuz din taassubunun daha detaylı bir şekilde romanda da yer aldığı; kadın, aile, evlilik temalarının her iki metinde de okunduğu, fakat hikâyede yer almayan siyaset, milliyetçilik, mezhepçilik, savaş, sömürü, gibi konuların Efendiyev tarafından romana dâhil edildiği görülür.

\section{Yapısal farklılıklar}

Yeniden-yazma, aynı zamanda edebî bir dönüştürmeyi içerir, bu dönüştürme yapısal ve anlamsal olabileceği gibi, sadece yapısal veya sadece anlamsal da olabilir. Biçimce ve anlamca dönüşürmenin altında estetik dönüştürme, ideolojik dönüştürme, ögretici dönüşü̈rme, ahlâkça dönüştürme, sosyolojik ve psikolojik dönüştürme gibi çok sayıda ara başlık altında toplayabileceğimiz bir açılım yer altr. $^{6}$ İnceleme konumuz olan metinler arasında da yapısal bakımdan benzerlikler

5 Ali Duymaz, "Sunuş Yazısı," Mahmut ile Meryem, Ötüken Yayınları, İstanbul 1997, s. 8.

6 C. Gariper - B. Küçükcoşkun, "Edebiyatta Yenidenyazma ve Nazan Bekiroğlu'nun Yusuf ile 
olduğu gibi önemli farlılıklar da söz konusudur. Farklılıklardan ilki ise eserlerin isimlerinde görülür.

Aslı ve Kerem hikâyesinde kahramanların asıl isimleri Mahmut ve Meryem'dir. Fakat hikâyenin akışında Mahmut kendi ismini Kerem, Meryem'in ismini de Aslı olarak değiştirir. Nitekim hikâyenin hemen bütün varyantlarında kahramanların isimleri Aslı ve Kerem (Anadolu sahasında Kerim ile Aslı) şeklinde geçer. Elçin Efendiyev ise romanının adını alt metne bağlı kalarak Mahmut ile Meryem olarak tayin eder ve kahramanlarının isimlerinde de herhangi bir değişiklik yapmaz. Olay örgüsü ise hem hikâyede hem romanda koşuttur, üç evreden oluşur. İlk evrede Mahmut ve Meryem, Gence'de dünyaya gelirler, burada birbirlerine âşı olurlar. İkinci evrede Meryem'in babası kızını Mahmut'tan ve Gence'den kaçırır, Mahmut da Meryem'i bulmak için yola koyulur; kısacası yolculuk başlar. Olay örgüsünün bu evresinde hikâye ile romanın birbirinden uzaklaştığı, hem yapı hem de anlam bakımından farklılıkların belirginleştiği dikkat çeker. Son evre ise birbirlerini bulan Mahmut ile Meryem'in hazin sonlarını ihtiva eder.

Mahmut ile Meryem romanında olayların gelişimi alt metinle koşut olmasına rağmen ona oranla hayli ayrıntılıdır. Bunda elbette ikincil metnin başlıca tür özelliği olarak "ayrıntı sanatı" olmasının rolü vardır. Zira roman, ayrıntıyı gerekli kılan bir türdür. Nitekim yukarıda da değindiğimiz gibi hikâyede olmayan, Efendiyev tarafından romana dâhil edilen birtakım olaylar yer alır. Bunlardan ilki Mahmut'un doğumudur. Hikâyede Mahmut, Ziyad Han'ın oğlu, Meryem ise Kara Keşiş'in kızı olarak ülkede fakirlere verilen bir ziyafetten dokuz ay sonra ${ }^{7}$ aynı gün doğarlar. Romanda ise Ziyat Han'ın eşi Kamer Banu, "uyuz tilki” ile “dilsiz ucube"nin tavsiyeleriyle Göğçegöl'e gidip üç gün yıkanması sonucunda hamile kalır. Mahmut, "her şeye sahip olan ama bir evladı olmayan" Ziyat Han ve Kamer Banu'nun dokuz yıl süren çocuk özleminden, dokuz yıl süren derman arayışlarından sonra dünyaya gelir:

"Dilsiz adam, içinde tilkinin dolaştığı kafesi kucağına almıştı ve bomboz gözlerini Ziyat Han'a dikip konuştu: Kurban olduğumuz tilki bütün insanlar dokuz ayda doğar, sizinki dokuz yılda doğacak diye buyurdu!'YYıllar geçmişti ve Ziyat Han bu durumu tamamen unutmuştu (...) Tam dokuz ay sonra, baharın sonlarında Cevza burcunda Mahmut dünyaya geldi (s. 29).”

Züleyha Adlı Anlatısı," Sonrası Türk Romanı (Sempozyum Bildirileri), Erciyes Üniversitesi Yayınları, Kayseri 2008, s. 668.

7 Hikâyenin diğer bazı varyantlarında doğum, dervişin verdiği elmayı Han'ın ve Keşiş'in eşlerinin yemesiyle geçekleşir. Bkz. Ali Duymaz, Kerem ile Aslı Hikâyesi Üzerinde Mukayeseli Bir Araştırma, Kültür Bakanlığı Yay., Ankara, 2001. 
Romanda Meryem'in doğumu ve ailesi konusunda da hikâyeye göre bazı ilavelerin, eksiltilerin, değişikliklerin olduğu göze çarpar. Meryem' in doğumuna dair olağanüstü özellikler taşıyan herhangi bir olay yoktur. Tam tersine, doğum sırasinda Meryem'in annesinin ölmesi, ilerleyen yıllarda Meryem'in bu sebeple kendini suçlu hissetmesi, Baba Keşiş’in kendini kızına adaması gibi olayları, modern okuyucunun gerçeklik algısına yönelik anekdotlar olarak düşünmek mümkündür.

Aslı ve Kerem hikâyesi ile Mahmut ile Meryem romanı yapısal bakımdan karş1laştırıldığında iki metnin tür özelliklerini de göz önünde bulundurmak gerekir. Alt metin bir halk anlatısıdır ve modern bir metin olan Mahmut ile Meryem'in yapısal imkânlarından yoksundur. Roman türünün genişlemeye, ayrıntıya inmeye, tasvir, tahlil, monolog, bilinç akışı vb. anlatım tekniklerinden yararlanamaya açık bir tür olması, romancının anlatısı için uygun gördüğü söz konusu tekniklerden seçme yapmasını olanaklı kılar. Nitekim iki metin arasındaki yapısal unsurlar karşılaş̧ırıldığında benzerliklerin yanında önemli farklılıklarında da olduğu görülür. Anlatıcı ögesi hususunda iki metnin birbirinde çok uzak olduğunu söylemek pek mümkün değildir. Her iki anlatıda da tanrısal anlatıcı, metinleri aktarma görevi üstlenmiştir. Ancak Mahmut ile Meryem'de anlatıcı, yer yer bakış açısı ve anlatım tutumuyla metne dâhil olur. Söz konusu anlatıcı, kişi ve olayların geçmiş ve gelecekleri hakkında geniş bir bilgiye sahiptir ve bu bilgiler sık sık okuyucuya aktarılır. Romanda anlatıcı hususunda görülen bir detay da bazı roman kişilerinin ben anlatıcı olarak kurguya dâhil edilmesidir. Sofu'nun Mahmut'la olan yolculuğunu anlattı̆̆ 1 ve Ziyat Han'a gönderdiği mektup, ben anlatıcı tipine örnek teşkil eder. Romanda anlatma yönteminin dışında gösterme(sahneleme) ve özetleme yönteminin de hikâye ile koşut olduğu söylenebilir. Fakat hikâyede kullanılmayan ya da çok sınırlı kullanılan tasvir ve iç çözümleme teknikleri romanı alt metinden farklı kılan önemli ayrıntılar olarak dikkat çeker. Eserde kişileri tanıtmak için yapılan tasvirlerden daha çok mekânların tanıtımında kullanılan tasvirler ağırlıktadır. Savaş sonrası Çaldıran Ovası'nın, cemaatin ve Azer'in köyünün yer aldığı sayfalar, tasvir tekniğinin en yoğun kullanıldığı bölümlerdir. Aşağıya Çaldıran ovasının tasvirini alıyoruz: $O$ boz karaltı kesilmiş insan başlarından yapılmış bir piramitti. Kargalar, kuzgunlar bu kellelerin birçoğunun gözünü çıkarmıştı, ama bazı kellelerde tek tük gözler kalmıştı ve neredeyse firlayıp yuvalarından çıkacak bu büyümüş tek gözler bütün Çaldran ovasını örtmüş başsiz cesetlere bakiyordu ...(s. 107).

Sözlü veya yazılı her tür anlatının mutlaka ihtiyaç duyduğu mekân ögesi; olayların cereyan ettiği çevreyi tanıtmak, anlatı kişilerini çizmek, toplumu yansitmak, atmosfer yaratmak gibi çeşitli amaçlar doğrultusunda kullanılabilir. ${ }^{8}$ Aslı ve 
Kerem hikâyesi ile Efendiyev'in romanının mekân ögelerinin de her iki anlatıda benzer işlevlerde kullanıldığını söylemek mümkündür. Fakat mekân çeşitliliği bakımından ikincil metnin alt metne göre daha zengin olduğu ve bunların genellikle bazı iletiler vermek için romana yerleştirildiği görülür. Hikâye ile romandaki ortak olan mekânlar Gence şehri, bu şehirdeki Ziyat Han'ın sarayı, Erzurum vb. Hikâyede Aslı ve Kerem'in uğrak yerleri olan Gürcistan, Kayseri ve Halep şehirlerine ise romanda rastlanmaz. Buna karşın Keşiş'in Gence'deki küçük, mütevazı evi, Çaldıran Ovası, Azer'in köyü, Mukaddes ev, Süleyman'ın Erzurum'daki sarayı da hikâyede yoktur. Efendiyev'in romanında kurguladığı mekân ögelerinin ise bir düşüncenin, durumun yahut niteliğin yansıması veya timsali olduklarını söylemek mümkündür. Keşiş’in Gence'deki evi sadeliği ve mütevazılı̆̆g; Çald1ran Ovası savaşın dehşetini, Azer'in köyü mezhepsel yozlaşmayı, Mukaddes ev dinsel (Hıristiyan) taassubu, Süleyman Paşa'nın Erzurum'daki sarayı ise (oryantalist bir imge sezilir) Doğulu Müslüman yöneticilerinin yaşantısını temsil eder.

Aslı ve Kerem hikâyesinde zaman unsuru sabah akşam, gece gündüz şeklinde kozmik olarak karşımıza çıkar. Hikâyenin tarihsel bir kişi, olay ya da durumu içerdiği, bunlara gönderme yaptığı söylenemez. Mahmut ile Meryem romanında ise zaman unsuru hem teknik hem de tematik bakımdan önemli işlevler yüklenmiştir. Romanda anlatı zamanı ile vaka zamanı farklılık arz eder; sık sık geriye gidişler, ileri sıçrayışlar görülür. Roman, kesin tarih belirten Hicrî 920 yll $\mathrm{Cema-}$ ziyülevvel ayının 4'ü, milâdî 1914 yılı Haziran ayının 28'i idi' (s. 11) cümlesiyle başlar. Anlatı zamanı da bu tarihleri içerir. Ancak Ziyat Han'ın, Kamer Banu'nun, Keşiş, Salman, Ceylan gibi roman kişilerinin geçmişlerine gidilerek onların anlatı zamanındaki duygu, düşünce ve eylemlerinin sebeplerinin açıklandığ 1 görülür. Romanda zaman unsuru konusundaki en önemli tasarruf ise siyasal olayların eserin arka planına yerleştirilmesidir. Yazar, eserin anlatı zamanında meydana gelen Çaldıran Savaşı'nı kurguya taşıyarak Şah İsmail-Yavuz Selim çatışmasının siyasal, sosyal, ekonomik, hatta bireyler üzerindeki psikolojik etkilerini göstermek ister.

Anonim bir anlatı olan Asll ve Kerem'de olaylar ve kişiler tasvir ve tahlile girilmeden yüzeysel bir şekilde anlatılır. Mahmut ile Meryem romanında ise Efendiyev, yeniden-yazma yönteminin genişletme ve yazı türünü değiştirme (düzyazılaştırma) imkânlarından yararlanarak alt metindeki olaylara ve kişilere yenilerini ilave eder. Böylece metnini genişlettiği, kişilerin duygu ve düşüncelerine daha fazla yer vererek onlara derinlik kazandırdığı, onları birer karakter haline getirdiği görülür. Roman kişilerinden Mahmut, duygusal ve düşünsel yönden hikâyedeki Kerem'e nispetle çok daha detaylı kurgulanmış, hatta Efendiyev, anlatı içinde onun işlevini değiştirmiştir. Hikâyede salt aşkı ile var olan Kerem'e 
karş11ık Mahmut, çocukluğundan itibaren farklı bir duruş sergilemiş, önceleri bütün zamanını sarayın kütüphanesinde geçirirken yolculuk esnasında kendi dışına çıkmış; siyasal, sosyal, dinsel konularda birtakım sorgulamalara, hatta belirgin eleştirilere girişmiştir.

Nitekim hikâyede Kerem'in yolculuğu aşka doğrudur. Yola çıkarken tek gayesi Aslı'ya ulaşmaktır. Yol boyunca gördüklerinin, yaşadıklarının ona duygusal ya da düşünsel herhangi bir katkısı olmamıştır. Romanın kahramanı Mahmut ise Meryem'i aramak için yola çıkmış, fakat yolculuk onun için âdeta "olgunlaşma macerasına" dönmüştür. Mahmut'un, Çaldıran Ovası'nda savaşın dehşetini görmesi, savaşta ölenlerin insan olma özelliklerini ve haklarını vurgulaması, savaşı çıkaranlara ise isyan etmesi, bu durumu en belirgin şekilde örnekleyen anekdotlardan biridir. Yine romanın sonundaki Meryem'e kavuşma anlarında kendisini bile şaşırtan duygular içindedir:

"Meryem onun olacaktı. Peki, niçin şimdi bütün bunları düşünmüyor, Meryem'i düşünmüyor da kırmızı şalvarlı (Azer) adamı düşünüyordu (...) Mahmut babası hakkında düşünmek istiyordu, ama gözlerinin önüne palana kıyamadığ için cemaatin öldürdüğü o bedbaht ihtiyar geliyordu. Mahmut bütün iradesini topluyor, bu bedbaht ihtiyarın sıfatına babasının çizgilerini vermek istiyordu, onun yerine babasını görmek istiyordu ve bir müddet görüyordu da... Ama sonra bu görüntü karga kuzgunun yüzünü gözünü didiklediği binlerce kelleye dönüşüyordu ve Mahmut Çaldıran ovasındaki o kelle kulesini görüyordu. $\mathrm{Bu}$ kellelerden her birinin sahibi de insand 1 ve bu insanların da evladı vard1, anası babası vardı ve bu insanlar da şu gökyüzünün altında yaşıyordu...(s. 215).”

Bütün bu gördükleri ve yaşadıkları ona kendi derdinin boyutlarını sorgulatmış, başkalarının ıstırap ve felâketleri karşısında kendi derdinin büyüklüğünden kuşku duymuş, hatta çoğu zaman bunu geriye atmıştır. Kısacası yolculuk, roman kahramanı Mahmut'u toplumsal bir varlık haline getirme süreci olmuştur. Ancak yazarın alt metne bağlılığının, bu sürecin tam anlamıyla başarıya ulaşmasına engel olduğunu belirtmek gerekir.

Hikâye ve romandaki ortak kişilerden biri olan Aslı /Meryem, her iki anlatıda da edilgen bir konumda çizilir. Her iki metinde de hayatını yönlendiren ve belirleyen babasıdır. Romanda sakin, iddiasız bir karakter izlenimi vermesine rağmen Keşiş babası onu Hıristiyan safiyetinin timsali olarak görür. Hatta saflık, temizlik ve Hıristiyan dinindeki işlevi bakımından Hz. Meryem'e yaklaştırır. Yine ortak kişilerden Ziyat Han ve Sofu da iç çözümleme yöntemiyle psikolojik boyutları daha ayrıntılı işlenerek derinlik kazandırılan karakterler haline getirilmiştir. Ziyat 
Han'ın; oğlu Mahmut için, tahtı için, eşi Kamer Banu için düşündükleri, hissettikleri ve yaptıkları ise onu, hikâye kişisi Ziyat Han'dan ayırarak çok yönlü bir karakter hâline getirir.

Yine kişi kadrosu bakımından Aslı ve Kerem hikâyesinde kadın figür sayısı oldukça sınırlıdır ve kadınların gerek fiziksel gerekse ruhsal tasvirlerine -metin türünün özelliklerinin de etkisiyle- yer verilmemiştir. Mahmut ile Meryem romanında ise özellikle Kamer Banu ve Ceylan, kadın olma nitelikleriyle anlatıda ayrıntılı olarak işlenen figürlerdir. Aslı ve Kerem anlatısında Mahmut'un annesi Kamer Banu'nun adı hiç geçmemekte; Efendiyev'in romanında ise Kamer Banu, özellikle anne işleviyle öne çıkarılmakta, annelik duygusuyla giriştiği birtakım entrikalar ve bunun yanında Ziyat Han'ın ve Mirza Salman'ın ona hissettikleri aşk dolayısıyla bir roman karakteri kimliğine bürünür. Ceylan ve Kısır Karı da hem hikâyede hem romanda görünen figürlerdir. Ancak romanda her iki kadınına yüklenen işlevler hikâyeden oldukça uzaktır. Romanda Ceylan, çocukluğunda kimsesiz kaldığı için erkekler tarafından istismar edilen, ilerleyen yıllarda ise gayri ahlaki davranışlarıyla maddi bakımdan güçlenip geçmişte yaşadıklarının intikamını almak isteyen bir karakter görünümündedir. Kısır Karı ise halk hikâyelerinde sık karşılaşılan "ucube motifinin" karşılığg gibidir. Yine her iki metinde Mahmut'un refakatçisi olarak konumlanan Sofu'nun da hikâyedeki işlevi ile romandaki işlevi arasında önemli farkl11ıklar olduğunu belirtmek gerekir. Sofu, hayatı boyunca önce Kamer Banu'ya, sonra da Mahmut'a hizmet etmiştir. Ancak yolculuk Mahmut’ta olduğu gibi onun iç dünyasında da birtakım değişimlere, ruhsal dönüşümlere sebep olur. Hikâyede Mahmut'a daima sadık kalan, her koşulda onun yanında olan Sofu, romanda daha yola çıkmadan tereddütler yaşayan biridir: Aslında Sofu, rahat yorgan döşeğini, hazır yemeğini sarayda bırakıp derviş gibi çöllere düşmek istemiyordu (s. 94). Nitekim yolculuk boyunca rahatsızdır. Bir an önce geri dönmek ister. Hayata nesnel yaklaşan; hissettiğine, sezdiğine değil, gördüğüne inanan Sofu, Mahmut'un derviş tabiatı karşısında kimi zaman şaşkınlık, kimi zaman da rahatsızlık duyar. Onu kendi kendiyle mücadeleye sevk eden ise Ziyat Han'ın, Mahmut'un ihtiyaçlarını karş1lamak için Mahmut'tan habersiz olarak kendisine emanet ettiği mücevherlerdir. $\mathrm{Bu}$ mücevherler onu yol ayrımına sevk eder. Başkalarına hizmetle geçen yıllarını kayıp olarak değerlendirir ve uzun bir muhasebenin sonunda mücevherleri de alarak Mahmut'u terk eder. Denilebilir ki romanda en zorlu psikolojik sinava Sofu tâbi tutulmuş, romanın sonunda ise sınavı kaybetmiştir.

Roman kişilerinden Bayındır Bey, Mirza Salman ve Süleyman Paşa gibi figürler hikâyede yer almayan, Efendiyev'in metnine eklediği kişilerdir. Akıllı ve kurnaz biri olan Bayındır Bey, çalışkanlığı ve cesaretiyle Ziyat Han'ın gözdesidir. Fakat Ziyat Han'ın ölümü onun eliyle gerçekleşir. Bayındır Bey, dönemin siyasal 
çekişmeleri ve taht mücadelelerini anlatmak maksadıyla romana eklenen bir kişi izlenimini verir. Sarayın kütüphane müdürü Mirza Salman ise derin kültürü ve Kamer Banu'ya olan aşkıyla dikkat çeker. Erzurum dağlarında Mahmut'la karş1laşarak onu sarayına getiren, ardından Meryem ile Keşiş’i buldurarak iki âşığın düğünlerini yapan Süleyman Paşa da romana hem engelleri ortadan kaldıran hem de Turan ideolojisinin sözcülüğünü üstlenen bir işlevle dâhil edilmiştir.

\section{Anlamsal farklılıklar}

Aslı ve Kerem hikâyesinde hiç değinilmeyen siyasal faaliyetler, Meryem ile Mahmut romanına yazar tarafından ilave edilen önemli temalardan biridir. Mahmut'un babası Ziyat Han üzerinden dönemin iki hükümdarı, Şah İsmail ve Yavuz Sultan Selim arasındaki siyasal çekişmeler, bu çekişmelere karşı Ziyat Han'ın izlediği denge politikası, sonrasında çıkan Çaldıran Savaşı'nı Yavuz Sultan Selim'in kazanması, bunun üzerine Ziyat Han'ın yerine Yavuz Selim'e daha yakın isim olan Bayındır Han'ın tahta geçmesi, hemen ardından da Ziyat Han'1 öldürmesi romanın siyasal ve tarihsel fonunu oluşturur. Yine hikâyede olmayıp romanda karşımıza çıkan ve siyasal uzantısı olan bir anekdot da Mahmut'un annesi Kamer Banu'nun, oğlu Mahmut'a taht mücadelesinde rakip olabilecek Ziyat Han'ın kardeşi Cavanşir'i katlettirmesidir. Kamer Banu'nun bu davranışını annelik güdüleri yanında siyasal hırsına, her sarayda varlığ 1 bilinen iktidar mücadelesine, saray entrikasına bağlamak mümkündür. Bunun yanında hikâyedeki silikliğinin karşısında romanda bir karakter olarak var olduğu şeklinde okumak da mümkündür:

“Kamer Banu eşkıya başı Göyçek Kellöz’le anlaştı. Eşkıya başı Göyçek Kel-
löz, Murov Dağı'nda yaban keçisi avına çıkan Cavanşir Han'ı gizlice izledi;
okla vurup öldürdü. Sonra da bu sır hiçbir zaman ortaya çıkmasın diye yine
altın gücüyle saray muhafızı Tekgöz Velikulu ile anlaştı. Tekgöz Velikulu da
pusu kurup Göyçek Kellöz'ü gece yarısı Gence'de sevgilisi Haykanuş’un
yanına geldiğinde hançerle doğradı. Sonra bu sırrı Allah’tan ve Kamer Ba-
nu'dan başka kimse bilmesin diye kendi elleriyle Tekgöz Velikulu'nu zehir-
leyip öldürdü (s.: 52).”

Her iki anlatıda koşut olan ama içerik bakımından önemli farklar barındıran unsur ise yolculuk metaforudur. Yolculuk metaforu hikâyede sevilen kişiye ulaşma, bireysel mutluluğu yakalama sürecini ifade eder. Fakat romanda bir yandan tarih boyunca insanlığın ortak dramlarını teşkil eden açlık, sömürü, savaş vb. olgulara dair birtakım sahnelerin betimlenmesine, bunlara yönelik eleştirilerin ortaya konmasına imkân sağlar, bir yandan da Mahmut'un, Sofu'nun ruh dünya- 
larında değişimlere, dönüşümlere yol açar. Denilebilir ki yolculuk, gerek Mahmut'un gerekse Sofu'nun zorlu sinavlara tabi tutulduğu bir arketip işlevi görür. Hikâyede Aslı'yı arayan, ona ulaşmaya çalışan Kerem, yolculuk boyunca karş1laştı̆g 1 kişilere, canlı veya cansız varlıklara Aslı'yı sorar, onu bulmasına yardım edecek bilgiler edinmeye çalışır. Dağlardan, derelerden, köylerden, şehirlerden geçer; buralarda karşısına çıkan erkeklere, kadınlara derdini anlatır, kadınların bazılarını Aslı'ya benzetir. Kısacası Kerem'in zihni bütünüyle Aslı ile meşguldür. Romanda ise hikâyeye göre çok farklı bir yolculuk gerçekleşir. Kişisel mutluluğun aranışı olarak başlayan yolculuk, yol boyunca görülenler, tanık olunanlar, maruz kalınanlar dolayısıyla insanî kaygılara dönüşür, evrensel değerlerin vurgulandığı bir metafor niteliğine bürünür. Söz konusu metafor, insanlığı tahrip eden birçok dramı içerir. Bunlardan biri savaştır.

Mahmut ile Meryem romanında savaş, Mahmut ve Sofu'nun yolculukları s1rasında Çaldıran Ovası'nda gördükleri üzerinden verilir. Romanın iki figürü savaşın korku verici yüzüyle bu ovada karşı karşıya gelirler. Bu ovada beş gün önce Osmanlı ve Safevi devletleri arasında bir savaş başlamış, üç gün sürmüş ve bu savaş dolayısıyla bu ovanın adı tarihe yazılmıştır. ${ }^{9}$ Romanda ovanın betimlemeleri dehşet vericidir. Sofu, uzakta bir küme kara bulut görür, yaklaştıkça o kara bulut kümesinin yırtıcı kuşlar olduğunu, bu kuşların boz bir karaltının üzerine inip kalktıklarını fark eder: $O$ boz karaltı, kesilmiş insan başlarından yapılmış bir piramitti. Kargalar, kuzgunlar bu kuleleri ditmişti (...) Bu başsız cesetler birbirine karışmıştı, demir zırhları, elbiseleri kana, toprağa bulaşmıştı. Her taraf kılıç, kalkan, mızraktı ve bu demirler güneşin ışıkları altında parlıyordu (s. 107).

Efendiyev, hikâyedeki işlevi Hak aşığı olan Kerem'i karakter bakımından dönüştürerek onu evrensel değerlerle donatıp insan aşı $\breve{g} 1,{ }^{10}$ hümanist Mahmut haline getirmek ister. Bu yüzden de Mahmut, mensubu olduğu din, kültür, millet vb. olguları sorgulamaya girişir. Çaldıran Ovası'nda gördükleri karşısında yöneticilere âdeta isyan eder: Sofu! Sofu! Beş karlş toprak için mi? bir kese altın için mi? çocuk olmamış mı bunlar? Gögü, ayl, yıldızları görmemiş mi bunlar? Şümr olup birbirlerinin başını kesiyorlar, Allah buna nasıl dayanıyor Sofu (s. 106)

Hikâyede olmayan, romana ilave edilen bir başka önemli anekdot da "cemaat" olarak adlandırılan küçük topluluktur. Mahmut, Sofu'nun kendisini terk

9 Söz konusu savaş, 1514 yılında Osmanlı Hükümdarı Yavuz Sultan Selim ile Safevi Hükümdarı Şah İsmail'in orduları arasında bugün İran sınırları içindeki Çaldıran Ovası'nda geçmiş, Osmanlı'nın galibiyetiyle sonuçlanmıştır.

10 Nazım Hikmet de "Kerem Gibi" şiirinde, Kerem ile Aslı hikâyesinin erkek kahramanı Kerem'in, aşk uğruna yanma motifini ideolojik bir dönüştürmeyle "devrim uğruna yanma" motifine çevirir. 
etmesiyle yalnız kalır ve ilk defa insana ihtiyaç duyar. Bu yüzden de tanımadığı iki kişiyle birlikte cemaate dâhil olur. Bu cemaat, katillerden, hırsızlardan, ahlaksızlardan, evsizlerden kısacası toplumun "öteki kesiminden" meydana gelmiştir. Her birinin toplumsal bir kesime karş1lık gelmesi, birbirlerine ve Mahmut'a karş1 sergiledikleri tutum ve davranışlarıyla cemaat, romana karnavalesk bir boyut kazandırır. Hatta bu karnaval ortamında ${ }^{11}$ yer yer gotik görüntülerle karşılaş1ır. Mahmut, bu ortamdaki sefalet dolayısıyla üzülerek onlara yardım etmesi için Allah'a yalvarır. Fakat cemaattekiler, Mahmut'u "deli” olarak görürler ve ölçüsüz bir şekilde onunla alay ederler:

"Bedheybet Muhtar (...) Mahmut'a bakarak etrafinda dolanmaya başladı. Birden kurumuş elini Mahmut'un yüzüne basıp bağırdı:

- Âl-i abaya ant olsun ki deli bu! Deli bu! Deli bu!(...) Bedheybet Muhtar'1n kuru elinin uzun, kaba ve kapkara kirli tırnakları Mahmut'un alnına saplandı. Bu tırnakların saplandığı yerlerden ince kan damlaları süzülüp Mahmut'un kaşlarının üstünden gözlerine aktı. Birisi bağırdı:

-Avcıdır bu, gözlerinden kan damlıyor!

Cemaat gülmekten neredeyse kendini kaybediyordu bağıra çağıra sabahtan beri sefih sözler söyleyen bu deliyle alay etmeye başladılar:

-Bundan kan kokusu geliyor! Cemaat gürültüye boğuldu.

-Cin başı kesmiş bu! Cemaat eline geçeni keyifle Mahmut'un başına atmaya başladı.

Mahmut iki kolunu da açmış sanki bütün cemaati kucaklamak istiyordu. İnsanlar! İnsanlar! İnsanlar!

(...) Cemaat gülmekten katıla katıla daha fazla bir hırs ve keyifle eline geçeni Mahmut'un başına firlatmaya başladı. Taş, kömür, odun, at kemiği... (s. 185).”

Efendiyev'in, toplumun dışına itilmişleri ve onların içinde bulundukları sefaleti göstermek maksadıyla romanına dâhil ettiğini düşündüğümüz bu küçük topluluğun bir "yer altı sahnesini" andıran ve Mahmut'a yönelik taşkınlıklarını, ötekilerin ötekileştirmesi şeklinde okumak mümkündür. Yine bu sahneler aracıl1-

11 Karnavalesk (karnaval ortamı), gülmeyle doğrudan ilgisi bulunan; toplumsal yaşamın bütün kurallarının, değerlerinin ters yüz edildiği, kutsal olana dokunulduğu, resmî yahut gayri resmi yapıların alaya alındığı mizah ve ironiyle kurulan bir çılgınlık ve oyun dünyasıdır ( $R$. Harland'dan akt. Sözen, ). "Bakhtin'in Romanda "Karnavalesk” Kavramı ve Sinema”, Akdeniz Sanat Dergisi, C.2, S.4, 2009, s. 66. 
ğıla Efendiyev'in, açlık ve sefalet içindeki insanları “cemaat tiplemesiyle gözler önüne serdiği" ${ }^{\prime 2}$ söylenebilir.

Mahmut ile Meryem romanında yazarın metnine ilave ettiği ve yine yolculuk sırasında "Sarışın Oğlan" vasıtasıyla ortaya koyduğu bir başka tema da milliyetçiliktir. Romanın son bölümlerinde Erzurum hâkimi Süleyman Paşa olduğunu öğrendiğimiz Sarışın Oğlan'ın, henüz yazar tarafından kimliği ifşa edilmeden, Mahmut'la olan konuşmaları sırasında ideolojik fikirlerini öğreniriz. Romanda o da tıpkı Mahmut ve Sofu gibi insanlığın azap içinde olduğunu vurgular. Yalnız Mahmut ve Sofu'dan farklı olarak bu durumun sebebini iki büyük Türk devletinin -Osmanlı ve Safevi- mezhepçilik güderek birleşmemesine bağlar ve halkın çektiği açlık ve sefaletin giderilmesinin ancak Türklerin birleşmesiyle gerçekleşeceğini iddia eder. Romanın son bölümlerinde yazar tarafından kimliği açıklanan Süleyman Paşa'nın, milliyetçiliğin ötesinde Turancılık idealine bağlandığı, bu ideolojiye ilişkin olarak fikirlerini dile getirir. Yine romanda Mahmut'un düşünceleri yoluyla Yavuz Sultan Selim'in şahsında sünnî İslâm'a, Şah İsmail'in şahsında da şî̂ İslam'a eleştiriler yapılır. Bununla birlikte Şah İsmail ve şiî İslam'a yöneltilen eleştirilerin Yavuz Sultan Selim ve sünnî İslam'a yöneltilen eleştirilere nispetle biraz daha yumuşak olduğu görülür (s. 91-193). ${ }^{13}$

Romanda okunan ve yöneticileri hedef alan sosyal eleştirilerden bir başkası da ülke gelirleri ve kaynaklarının yöneticiler tarafından halkın yararına kullanılmaması, bir bakıma halkın sömürülmesi konusundadır. Bir ülkenin hazinesi, halkının ihtiyaçlarını karşılamaya hizmet etmelidir. Fakat Mahmut ile Meryem romanında Gence Hanlığının hazinesi; Ziyat Han, eşi Kamer Banu ve oğlu Mahmut'un -haberi olmasa da- istek, arzu ve mutluluğu için kullanılır. Ziyat Han, yolculuğu sırasında oğluna refakat edecek olan Sofu'ya hazinenin en kıymetli mücevherlerini seçip verir. Çünkü Ziyat Han'a göre hazine kendisine aittir ve kendisinin tek varisi de Mahmut'tur: Hindistan'dan, Çin'den, Irak'tan, Yemen'den, Habeşistan'dan Mağrip'ten getirilmiş, parayla alınmış, tehditle korkutmayla toplanmış, kılıç gücüyle gasp edilmiş bu iri elmasların, zümrütlerin, firuzelerin, yakutların hepsi Mahmut'un olmalıydı (s. 95).

12 Ali Duymaz, "Sunuş Yazısı," Mahmut ile Meryem, Ötüken Yayınları, İstanbul 1997, s. 8.

13 Sedat Adıgüzel, Sovyet dönemi Azerbaycan edebiyatında bu tür anlatımların dönemin belirgin özelliklerinden biri olduğunu kaydederek aslında yazarın eleştirilerin hedefinde Sovyet yönetiminin olduğunu, ancak sansürden kurtulmak için eleştirilerini tarihe yönelttiğini belirtir. Bkz. Sedat Adıüzel, Elçin Edebiyat Sosyolojisi Açısından Romanları, Bengü Yayınları, Ankara 2011, s.267-269. 
Yol boyunca kendi kendisiyle mücadele etmesine, yaşadığı hayatı ve bu hayatın içindeki konumunu, işlevini sorgulamasına sebep olacak bu mücevherleri gördüğünde Sofu'nun aklından geçenler ise anlatıcı tarafından aktarılır: Sofu, Ziyat Han'ın varlıkll, devletli olduğunu biliyordu; ama hiçbir zaman bu kadar mücevherin toplanıp bir yerde ve hepsinin de bir kişiye ait olabileceği aklına gelmemişti (s. 9).

Gerek Aslı ve Kerem hikâyesinde gerekse Mahmut ile Meryem romanında din taassubu temel problemlerden biridir. Hatta her iki anlatıda da başkişilerin birbirlerine kavuşmalarını engelleyen tek sebeptir. Bu taassup hem hikâyede hem de romanda Meryem'in babası Kara/Baba Keşiş üzerinden betimlenir. Hikâyede Kara Keşiş'in dinsel taassubu, kızı Meryem'in Mahmut'la evlenmesini engellemek için Gence'den kaçırarak Anadolu'ya kadar uzanan zorlu bir yolculuğu göze almasıyla gösterilir. Romanda ise bu taassup, Keşiş’in eylemlerinin yanında anlatıcının, Keşiş’in iç dünyasını aktardığı bölümlerde verilir. Bu bölümlerde Keşiş'in, Hıristiyanlık'1 en aşırı biçimde benimsediği, İslâmiyet'e ve İslâm mensuplarına karşı ise derin bir nefret hatta kin duyduğu okunur. Onun nazarında Hıristiyanlık saflığın, temizliğin, doğruluğun dinidir. Bu dinin temsilcisi ve özelliklerinin taşıyıcısı ise kızı Meryem'dir: Meryem aslında sadece Baba Keşiş'e ait değildi, bütün Allah adamlarının, Hıristiyanlarındı ve Meryem bir Hıristiyan kulu mesut etmeliydi. Meryem, ana olmalyydı ve Meryem dünyanın en temiz $\mathrm{Hl}$ ristiyan çocuklarını doğurmalıydı (s. 124).

Mahmut ile Meryem'de din taassubu Hıristiyan bir figüre yüklenirken Müslüman figürler üzerinden de mezhep ayrımcılığına ve bu yolda çıkan çatışmalara eleştiriler getirilir. Romanda Azer ve Aysulu'nun köyünde yaşanan olaylarda bu eleştiriler sezdirilerek ortaya konur. Adı verilmeyen köy güzel iklimi, verimli toprakları, sağlıklı, güçlü, çalışkan insanları ve barış içinde yaşayan halkı ile şairlerin cennetten de üstün tuttuğu bir köydür. Fakat zamanla küçük anlaşmazlıklar, önemsiz farkl11ıklar büyümeye, aklın, anlayışın, iş ve emeğin, zenginliğin yerini anlayışsızlık, tembellik, öfke; fakirlik almaya başlar. Köyün düzeni bozulur ve çöküş içindeki bütün topluluklarda olduğu gibi bir kurtarıcı beklenir. Bu köy halkının beklediği kurtarıcı ise Azer-Aysulu çiftini on ikinci çocuklarıdır. Azer ve Aysulu'nun on bir tane oğulları dünyaya gelmiş, çocuklara Şiî imamlarının adları verilmiştir. Aysulu on ikinci çocuğuna hamiledir ve köy halkı doğacak çocuğu "Mehdi Sahibüzzaman" olarak beklemeye başlar. Fakat Aysulu bir kız çocuğu doğurur: Azer 'le Aysulu'nun on ikinci çocuğu kız olmuştu. Bu haber halkı ayak üstünde kuruttu, dizler titredi, kalpler durdu, gözler karardl, ahaliyi soğuk ter bastı. Sanki herkesin dili tutuldu, seslerini bile çıkaramadılar (s.165). Ancak bu sessizlik kısa biz süre sonra galeyana döner. Kandırıldıklarını hisseden, aslında 
kendi kendilerini kandıran doğru yolu şaşırmış köy halkı, tarihte birçok defa yaşanan kitlesel çılgınlıkların bir benzerini sergilerler. Efendiyev, romanın bu sayfalarında tüyler ürpertici bir atmosfer yaratır. Azer-Aysulu çiftinin on iki çocuğu da kalabalık tarafından vahşi şekillerde katledir. Cennetten üstün tutulan bir köyün ve böyle bir köyün halkının en vahşi sahnelerin yaratıcısı olmalarını, yazarın din ve mezhep taassubuna yönelik sert bir eleştirisi olarak okumak mümkündür.

\section{Sonuç}

Meryem ile Mahmut roman1, Azerbaycan ve Anadolu sahasında bilinen bir halk hikâyesinin yeniden-yazma tekniğiyle yeniden üretilmiş çağdaş bir metindir. Yeniden-yazma tekniğinin daha çok genişletme, anlamsal ve biçimsel dönüştürme yöntemini kullanan Efendiyev, sözlü geleneğe ait bir anlatıyı modern bir tür olan romana dönüştürürken olay örgüsüne bağl1 kalmakla birlikte yeni olaylar ve kişiler ekleyerek yapısal ve anlamsal bakımdan eserini genişletmiş, derinleştirmiş ve değiştirmiştir.

Alt metnin ismine sadık kalarak romanının ismini Mahmut ile Meryem olarak belirleyen Efendiyev, anonim bir anlatı olan ve nazım- nesir karışık şekilde oluşturulan bir metni çağdaş tekniklerle düzenlenen bir metin olarak kaleme almış, böylece alt metin biçimsel bir dönüşüme uğramıştır. Yazar, yeniden-yazma yönteminin genişletme imkânlarından yararlanarak da romanına, alt metinde bulunmayan olayları, kişileri, mekânları, motifleri eklemiş, böylece metninde yeni anlam alanları yaratmıştır. Romana eklenen her kişi, bir düşünce veya sorunu temsil eder özelliğe sahipken tespih tanesi gibi dizilen yan olaylar da benzer işlevlerde kullanılmışlardır.

Efendiyev, yeniden-yazmanın dönüştürme yönteminden de faydalanarak iki metinde ortak olan kişilerin karakterlerinde birtakım tasarruflarda bulunmuştur. Yazar, romanın başkişisi Mahmut'u yaşadığı çağa ve çevreye yabancı kılmış, kendisinden beklenenleri karşılayamayacak bir kişi olarak betimlemiştir. Mahmut'un bu özelliği, modern dönem insanının problemi olması bakımından önemlidir. Yine bireysel mutluluğunun peşinden giden hikâye kahramanı Kerem'e karşı1lık Mahmut'un, sonuca ulaşamamakla birlikte, evrensel değerler ışığında tüm insanların mutluluğunu arzulayan bir kahraman gibi çizilmek istendiği sezilmektedir. Hikâyede sadece eylemleriyle karşımıza çıkan diğer kişilerin de duygu ve düşünceleriyle betimlenerek roman karakterleri niteliği kazandırıldığını söylemek gerekir. Efendiyev, kişilerle olduğu gibi birtakım olaylarla da yeniden-yazmanın genişletme imkânlarından yararlanmış; Aslı ve Kerem hikâyesinde yer almayan siyasal, sosyal, kültürel ve ekonomik olayları/olguları, romanın arka planında bir fon olarak kullanmıştır. Böylece eserini alt metne karşı daha zengin kılmıştır. 


\section{Kaynakça}

Adıgüzel, Sedat, Elçin Edebiyat Sosyolojisi Açısından Romanları, Ankara, Bengü Yayınları, 2011.

Aktulum, Kubilay, Metinlerarası İlişkiler, Ankara, Öteki Yayınları, 2000. , "Yenidenyazma," Frankofoni (Ortak kitap), nr. 18, Ankara, 2006.

Duymaz, Ali, Mahmut ile Meryem (Sunuş Yazısı), İstanbul, Ötüken Yayınları, 1997.

, Kerem ile Aslı Hikâyesi Üzerinde Mukayeseli Bir Araştırma, Ankara, Kültür Bakanlığı Yayınları, 2001.

Efendiyev, Elçin, Mahmut ile Meryem, İstanbul, Ötüken Yayınları, 1997.

Elçin, Şükrü, Kerem ile Aslı Hikâyesi, Ankara, Akçağ Yayınları, 2000.

Gariper, C., Küçükcoşkun, Y., "Edebiyatta Yenidenyazma ve Nazan Bekiroğlu'nun Yusuf ile Züleyha Adlı Anlatısı," 1980 Sonrası Türk Romanı (Semp.Bild.), Kayseri, Erciyes Üniversitesi Yayınları, 2009.

Köprülü, M. Fuat, Türk Edebiyatı Ders Notları, haz. Y. K. Taştan, Ankara, Akçağ Yayınları, 2015.

Sözen, Mustafa, "Bakhtin'in Romanda "Karnavalesk" Kavramı ve Sinema", Akdeniz Sanat Dergisi, c.2, s.4, 2009.

Tehmasib, M. Hüseyn, Ahundov, Ehliman, "Esli ve Kerem," Azerbaycan Dastanlarl, c.2, Bakü, Lider Neşriyat, 2005. 